\title{
Perancangan Sistem Peminjaman dan Pengembalian Buku di Perpustakaan SMAN 2 Woha Berbasis Microsoft Access 2007
}

\author{
Nur Fitrianingsih ${ }^{1}$, Evi Afriani ${ }^{2}$ \\ ${ }^{1,2}$ STKIP Taman Siswa Bima \\ nurfitrianingsihp84@gmail.com
}

\begin{abstract}
ABSTRAK
Penelitian ini dilatar belakangi oleh permasalahan lambat dan tidak terkontrolnya pelayanan yang ada di perpustakaan SMAN 2 Woha. Hal ini dikarenakan sistem yang dipakai belum terkomputerisasi atau masih menggunakan sistem manual. Oleh karena itu, peneliti membuat suatu aplikasi sistem peminjaman dan pengembalian buku yang sudah terkomputerisasi. Dengan menggunakan aplikasi sistem ini, pelayanan perpustakaan SMAN 2 Woha akan lebih efektif. Penelitian skripsi ini bertujuan untuk menganalisa dan membuat aplikasi sistem peminjaman dan pengembalian buku di perpustakaan SMAN 2 Woha berbasis Microsoft Access 2007 yang dapat melakukan pelayanan yang dibutuhkan pada perpustakaan SMAN 2 Woha. Alat pembuatan aplikasi yang digunakan peneliti, yaitu Microsoft Access sebagai interface dan basis datanya. Metode penelitian yang digunakan adalah Waterfall. Dalam kesempatan ini, peneliti hanya membahas mengenai sistem pelayanan peminjaman dan pengembalian buku diperpustakaan SMAN 2 Woha dan hanya diterapkan pada perpustakaan SMAN 2 Woha.
\end{abstract}

Kata kunci: Waterfall, Microsoft Access, Sistem Peminjaman dan Pengembalian Buku.

\section{PENDAHULUAN}

SMAN 2 Woha adalah Sekolah Menegah Atas Negeri yang terletak di tengah persawahan perbatasan antara desa Kalampa dan desa Dadibou. SMAN 2 Woha ini merupakan salah satu sekolah di kecamatan Woha yang terus berbenah dengan melakukan berbagai terobosan, seperti fasilitas sekolah yang terus dibangun, untuk meningkatkan mutu sekolah layaknya pada sekolah favorit lainnya.

Perpustakaan sekolah adalah salah satu fasilitas yang disediakan oleh SMAN 2 Woha sebagai pendukung dan penunjang proses kegiatan belajar mengajar bagi para siswa. Keberadaan perpustakaan sangat membantu untuk menambah atau meningkatkan pengetahuan dan wawasan bagi para siswa serta sebagai wahana informasi yang dibutuhkan oleh siswa, guru dan karyawan yang ada di lingkungan sekolah, sehingga proses penyebaran informasi di SMAN 2 Woha dapat berjalan dengan baik.

Untuk membangun sekolah yang bermutu diperlukan adanya sebuah manajemen pada sekolah tersebut, dan salah satu ciri manajemen sekolah yang bermutu adalah sebuah sistem manajemen yang menerapkan penggunaan teknologi informasi dalam semua aspek pelayanan kepada peserta didik. Program aplikasi sistem komputer di perpustakaan bisa menjadi contoh pelayanan yang menarapkan penggunaan teknologi informasi.

Salah satu penerapan teknologi informasi di perpustakaan tersebut adalah pada layanan peminjaman dan pengembalian buku. Perancangan sistem pada layanan peminjaman dan pengembalian buku tersebut dapat mengontrol data buku dan data peminjaman buku dengan cepat dan baik. Layanan ini juga diperlukan dalam kemudahan proses input data, pengolahan data, dan proses output data.

Pada kenyataannya layanan peminjaman dan pengembalian buku di Perpustakaan SMAN 2 Woha masih menggunakan sistem manual. Dengan menggunakan sistem manual tersebut permasalahan banyak muncul. Pemustaka harus menunggu lama saat peminjaman maupun pengembalian buku karena sistem manual yang masih digunakan, yaitu masih menggunakan tulisan tangan. Seharusnya sistem manual ini sudah tidak dipergunakan lagi di perpustakaan, karena telah adanya perkembangan teknologi yang semakin maju dan berkembang. 
Salah satu program komputer yang dapat digunakan untuk mempercepat layanan peminjaman dan pengembalian buku adalah dengan menggunakan aplikasi sistem. Program pengolahan sistem yang digunakan adalah Microsoft Access. Microsoft Access 2007 merupakan program aplikasi komputer yang digunakan untuk merancang, membuat, dan mengolah berbagai jenis data dengan kapasitas yang besar. Disamping itu, Microsoft Access 2007 juga terkenal dalam kemudahannya sebagai aplikasi pengolah sistem, serta dapat dikembangkan lebih lanjut.

Penggunaan Microsoft Access 2007 contohnya seperti ada seorang petugas perpustakaan (librarian) akan jauh lebih efisien jika menyimpan kode bukunya dalam sebuah sistem. Bayangkan saja jika tiap jamnya ada pemustaka yang ingin pinjam buku, tentu petugas itu sangat kewalahan mencatat kode buku yang dipinjam. Alhasil ia pun memutuskan untuk membuat sebuah program aplikasi untuk perpustakaan. Dan ia akan memilih menggunakan Microsoft Access 2007, karena lebih mudah dan efisien waktu serta tenaga.

Menurut (Kristanto, 2004) Salah satu metode pengembangan sistem adalah metode Waterfall. Waterfall pertama kali diperkenalkan oleh Windows W. Royce pada tahun 1970. Waterfall merupakan model klasik yang sederhana dengan aliran sistem yang linier Output dari setiap tahap merupakan input bagi tahap berikutnya.

Perpustakaan merupakan salah satu sumber belajar penting dalam proses pembelajaran. Menurut UU Perpustakaan No.43 2007 "Perpustakaan adalah institusi pengelola koleksi karya tulis, karya cetak, dan atau karya rekam secara profesional dengan sistem yang baku guna memenuhi kebutuhan pendidikan, penelitian, pelestarian, informasi, dan rekreasi para siswa sebagai penggunaan perpustakaan”.

Microsoft Access menurut Ahmad Iskandar dalam modulnya yang berjudul Microsoft Access (Bandung,UNIKOM,2003) adalah “ Microsoft Access adalah salah satu software yang berjalan dibawah sistem windows, dengan Microsoft Access kita dapat merancang, memuat dan mengelola database dengan cara mudah dan cepat".
Microsoft Access digunakan kebanyakan oleh bisnis-bisnis kecil dan menengah, di dalam sebuah organisasi yang kecil bahkan mungkin juga digunakan oleh perusahaan yang cukup besar, dan juga para programmer untuk membuat sebuah sistem buatan sendiri untuk menangani pembuatan dan manipulasi data. Access juga dapat digunakan sebagai sebuah basis data untuk aplikasi Web dasar yang disimpan di dalam server yang menjalankan Microsoft Internet Information Services (IIS) dan menggunakan Microsoft Active Server Pages (ASP).

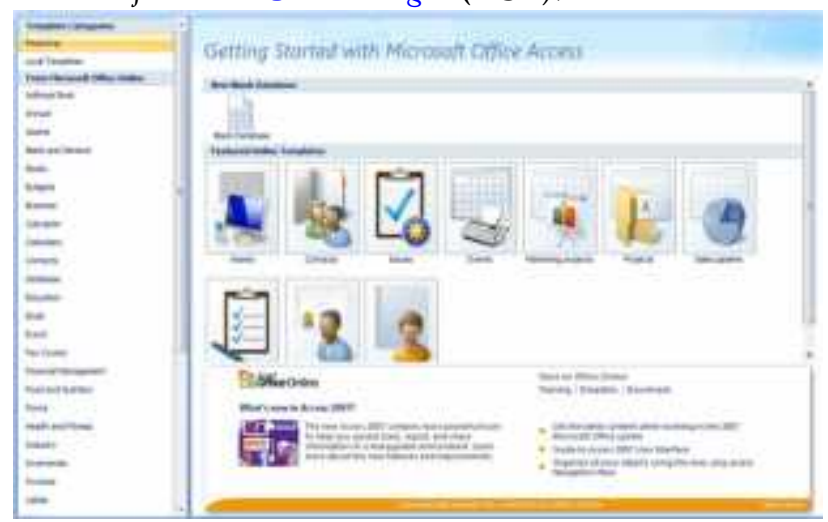

Gambar 1. Tampilan Microsoft Access 2007

Tujuan penelitian ini yaitu untuk mempermudah terkontrolnya data buku dan peminjaman buku dengan baik dan cepat menggunakan sistem berbasis Microsoft Access 2007.

\section{METODE PENELITIAN}

Pada dasarnya bagian ini menjelaskan bagaimana penelitian itu dilakukan. Materi pokok bagian ini adalah: (1) rancangan penelitian; (2) populasi dan sampel (sasaran penelitian); (3) teknik pengumpulan data dan pengembangan instrumen; (4) dan teknik analisis data.

Untuk penelitian kualitatif seperti penelitian tindakan kelas, etnografi, fenomenologi, studi kasus, dan lain-lain, perlu ditambahkan kehadiran peneliti, subyek penelitian, informan yang ikut membantu beserta cara-cara menggali data-data penelitian, lokasi dan lama penelitian serta uraian mengenai pengecekan keabsahan hasil penelitian.

Jenis penelitian ini adalah jenis penelitian pengembangan sistem, dengan menggunakan metode waterfall atau lebih dikenal dengan 
istilah siklus kehidupan klasik. Ciri khas dari air terjun adalah aliran searah dari atas ke bawah secara teratur. Begitu juga dengan model ini, setiap fase atau tahap dalam waterfall harus diselesaikan terlebih dahulu sebelum melanjutkan ke fase atau tahap berikutnya.

Pada metode waterfall ada 5 tahapan atau fase yang akan dilakukan yaitu, analisis, desain, percobaan, implementasi, dan terakhir pengoperasian dan pemeliharaan. Pada tahap awal akan dilakukan tahap analisis, setelah melakukan analisis baru kemudian desain, setelah itu lanjut ke tahap selanjutnya yaitu tahap percobaan, setelah sistem sudah selesai diuji coba, kemudian diimplementasikan, setelah melalui tahap implementasi baru melakukan tahap yang terakhir yaitu pengoperasian dan pemeliharaan.

Berikut ini akan diuraikan secara garis besar mengenai tahap-tahap siklus waterfall pada perancangan sistem peminjaman dan pengembalian buku berbasis Microsoft Access 2007 ini.

\section{Analisis (analysis)}

Dalam hal ini akan dilakukan analisis sistem lama dan mengidentifikasi apakah telah berjalan sesuai dengan standar. Semua hasil analisa akan gabungkan dan dipakai sebagai pedoman saat melakukan desain perancangan sistem.

Dalam tahap analisa sistem ini akan diuraikan mengenai: a) Penyimpanan data, Diuraikan tentang apa saja data yang disimpan pada penyimpanan data sistem yang lama; b) Sistem yang lama, Diuraikan mengenai tahapan proses peminjaman buku dengan menggunakan sistem yang lama; c) Identifikasi masalah, Diuraikan mengenai identifikasi masalah apa saja yang timbul mengenai sistem yang lama.

\section{Desain (design)}

Tahap selanjutnya adalah tahap desain. Pada tahap ini akan dilakukan pembuatan tabel, form, report dan query database peminjaman buku sesuai dengan data analisis yang sudah dilakukan. Untuk mendapatkan hasil desain yang sesuai dengan kebutuhan perpustakaan SMAN 2 Woha, maka akan dilakukan wawancara kepada ahli materi (petugas perputakaan) dan ahli media (dosen ahli).

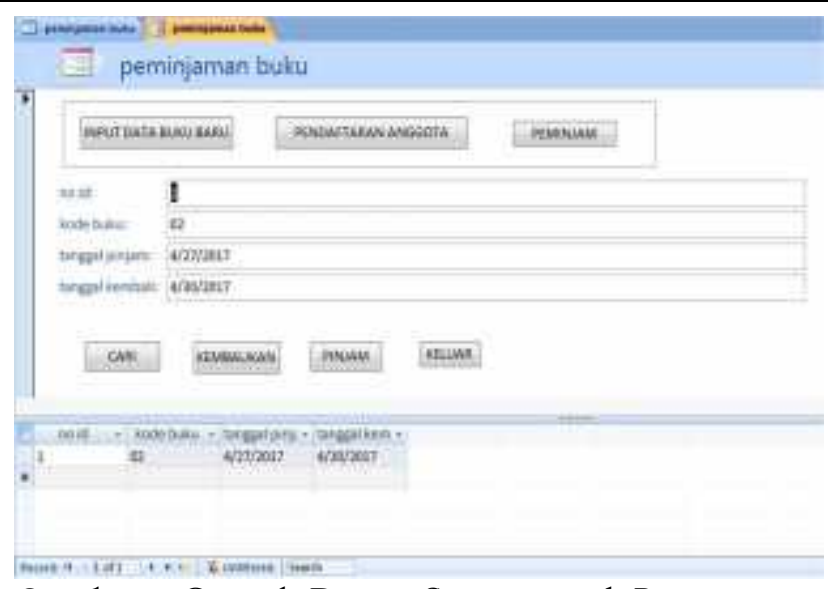

Gambar 2 Contoh Desain Sistem untuk Peminjaman Buku

Percobaan (testing)

Pada tahap ini akan dilakukan pengujian program secara keseluruhan dari sistem peminjaman dan pengembalian buku menggunakan Microsoft Access 2007 yang telah dibuat. Adapun uji coba dapat dilakukan dengan mengamati apakah program telah menerima input, memproses, dan menghasilkan output dengan benar. Percobaan akan dilakukan oleh petugas perpustakaan yang menangani data peminjaman buku.

Implementasi (implementation)

Tahap implementasi ini adalah proses untuk menerapkan sistem peminjaman dan pengembalian buku perpustakaan berbasis Microsoft Access 2007 yang telah dibangun agar user atau petugas perpustakaan menggunakannya menggantikan sistem yang lama. Pada tahap ini, akan dilakukan implementasi kepada petugas perpustakaan.

Implementasi dilakukan dengan beberapa proses, yaitu: a) Memberitahu user (notify user); b) Melatih user (user training); c) Memasang sistem (instal system) d) Entri atau konversi data (data entry or convertion).

Setelah berhasil melewati proses implementasi, berarti database peminjaman buku perpustakaan berbasis Microsoft Access 2007 ini sudah dapat menggantikan sistem yang lama.

Pengoperasian dan Pemeliharaan (operation \& maintenance)

Langkah paling akhir dalam model waterfall adalah pengoperasian dan pemeliharaan 
(operation \& maintenance) yang dijalankan selama sistem ini beroperasi.

Instrumen pengumpulan data dan informasi yang diperlukan menggunakan cara sebagai berikut: 1) Studi Pustaka, peneliti mengumpulkan acuan yang diperoleh dari buku, situs serta tulisan yang berhubungan dengan perancangan system; 2) Observasi, observasi dilakukan di perpustakaan SMAN 2 Woha, dengan mengamati aktivitas yang dilakukan oleh petugas perpustakaan dan pemustaka pada saat pelayanan berlangsung; 3) Wawancara, metode ini digunakan sebagai salah satu cara pengumpulan data dengan cara mengajukan berbagai macam pertanyaan kepada pihak perpustakaan SMAN 2 Woha.

\section{HASIL DAN PEMBAHASAN}

Bagian ini merupakan bagian utama artikel hasil penelitian dan biasanya merupakan bagian terpanjang dari suatu artikel. Hasil penelitian yang disajikan dalam bagian ini adalah hasil "bersih". Proses analisis data seperti perhitungan statistik dan proses pengujian hipotesis tidak perlu disajikan. Hanya hasil analisis dan hasil pengujian hipotesis saja yang perlu dilaporkan beserta dengan pembahasannya. Tabel dan grafik dapat digunakan untuk memperjelas penyajian hasil penelitian secara verbal. Tabel dan grafik harus diberi komentar atau dibahas.

Untuk penelitian kualitatif, bagian hasil memuat bagian-bagian rinci dalam bentuk sub topik-sub topik yang berkaitan langsung dengan fokus penelitian dan kategori-kategori.

\section{Perancangan Sistem}

Pada perancangan sistem peminjaman dan pengembalian buku ini, peneliti melakukan perancangan berdasarkan tahapan-tahapan dari metode waterfall antara lain :

\section{Analisis (analysis)}

Pada tahap ini peneliti melakukan analisis terhadap sistem yang lama antara lain:

a. Penyimpanan data

Pada tahap melakukan analisis penyimpanan data pada sistem yang lama di SMAN 2 Woha ada 2 data yang disimpan yaitu data inventaris buku dan data peminjaman buku. b. Sistem yang lama

Pada tahap penganalisaan selanjutnya adalah tahapan proses peminjaman buku menggunakan sistem yang sedang berjalan antara lain:

1) Pemustaka mencari buku yang akan dipinjam.

2) Pemustaka pergi ke meja petugas perpustakaan untuk meminjam buku.

3) Petugas menulis data pemustaka dan buku yang dipinjam pada data peminjaman buku.

c. Identifikasi masalah

Berdasarkan hasil analisa yang dilakukan terhadap sistem yang sedang berjalan, maka dapat diidentifikasi masalah apa saja yang terdapat pada sistem yang lama antara lain:

1) Penyimpanan data yang masih menggunakan sistem manual atau tulis tangan, yaitu menggunakan penyimpanan pada buku.

2) Penyimpanan data pada sistem yang lama hanya terbatas pada pencatatan data peminjam pada buku besar.

3) Data yang disimpan hanya data inventaris buku dan data peminjaman buku.

4) Membutuhkan waktu lama untuk mencari nama peminjam yang ingin mengembalikan buku.

5) Adanya kesulitan dalam melakukan pencarian riwayat data peminjam yang sudah lama disimpan.

2. Desain (design)

a. Desain Awal

Sebelum melakukan analisis terhadap sistem yang lama, terdapat desain awal yang telah peneliti buat yaitu sebagai berikut:

1) Desain Tabel

Pada data peminjaman buku terdapat empat kolom data yang akan di input (masukkan), antara lain:

a) No id, untuk memasukkan no id anggota yang sudah mendaftar pada data anggota perpustakaan. 
b) Kode buku, untuk memasukkan kode buku yang sudah mempunyai data pada data buku.

c) Tanggal pinjam, untuk memasukkan tanggal pada saat buku dipinjam.

d) Tanggal kembali, untuk memasukkan tanggal pada saat pemustaka mengembalikan buku yang telah dipinjam.

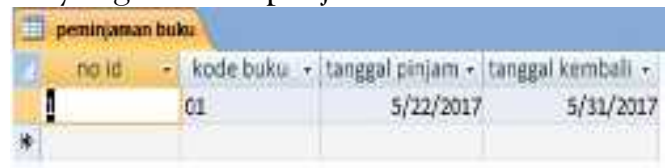

Gambar 3. Desain Awal Tabel Peminjaman Buku

Pada tabel data anggota (Gambar 4) terdapat lima kolom untuk menginput data yaitu no id, nama, kelas, alamat, dan no hp. Pada tabel data anggota ini digunakan untuk memasukkan data siswa yang ingin meminjam buku. Setiap pemustaka yang ingin meminjam buku wajib untuk mendaftar terlebih dahulu pada data anggota perpustakaan jika pemustaka tersebut belum terdaftar.

\begin{tabular}{|c|c|c|c|c|c|}
\hline \multicolumn{6}{|c|}{ Everijien } \\
\hline roid & tहाह & keles & - damat & $70,-P$ & - Lośles riaj \\
\hline 1 & hes & 22 & Ial & amose & \\
\hline 2 & sssids & wo & Iffeite & 7200658513 & \\
\hline & & & & & \\
\hline
\end{tabular}

Gambar 4 Desain Awal Tabel Data Anggota

Pada tabel data buku (Gambar 5) terdapat lima kolom untuk meng-input data yaitu kode buku, judul buku, pengarang, penerbit, dan tahun terbit. Masukkan data semua buku yang terdapat di perpustakaan pada kolom data buku sesuai dengan kode buku tersebut.

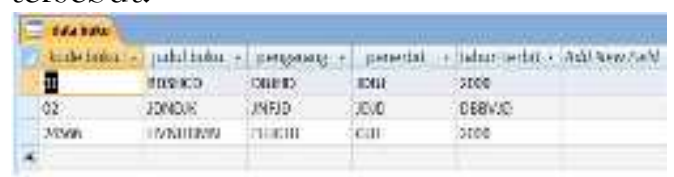

Gambar 5 Desain Awal Tabel Data Buku

2) Desain Form

Pada form peminjaman buku, data buku, dan data anggota terdapat beberapa button (tombol) dan combo box (kotak pencarian) yang akan digunakan antara lain: a) Tambah, button untuk menambahkan data yang baru. b) Simpan, button untuk menyimpan data. c) Hapus, button untuk menghapus data yang ingin dihapus pada setiap record (baris dalam tabel). d) Keluar, button untuk keluar dari form. e) Cari, combo box untuk melakukan pencarian pada data yang diinginkan.

Form peminjaman buku akan dijadikan sebagai halaman utama sistem, maka ditambahkan button antara lain: a) Input data buku, button untuk masuk pada form data buku, b) Daftar anggota, button untuk masuk pada form data anggota, c) Peminjam, button untuk masuk pada report data peminjaman buku,

3) Desain Query

Pada desain awal pembuatan query terdapat beberapa data yang sudah disaring untuk ditampilkan. Data query didapatkan dari data buku, data anggota, dan data peminjaman buku yang digabungkan menjadi satu data yang lengkap

4) Desain Report

Data report berasal dari data query yang diubah menjadi tampilan report, tujuannya yaitu untuk menampilkan data yang telah dirangkum secara efektif dan bisa dicetak.

b. Desain Akhir

Setelah melakukan desain awal, peneliti melakukan wawancara dengan ahli materi yaitu pak Haris (kepala perpustakaan) dan ahli media yaitu pak Zumhur Alamin (dosen) mengenai desain awal yang telah dibuat. Berdasarkan hasil wawancara dari kedua ahli tersebut maka terdapat perubahan dari desain awal sistem peminjaman buku adalah sebagai berikut:

1) Desain Tabel

Pada desain tabel peminjaman buku berdasarkan hasil wawancara dengan ahli materi, ditambahkan kolom jumlah buku untuk memasukkan data jumlah 
buku yang dipinjam, kolom lama pinjam untuk memasukkan berapa hari lama peminjaman, dan kolom denda untuk memasukkan jumlah nominal uang yang akan dibayar.

2) Desain Form

Berdasarkan pada hasil wawancara dengan ahli materi, terdapat perubahan pada desain form, perubahan yang dilakukan antara lain: a) Warna form. b) Letak button. c) Nama form. d) Combo box cari diubah menjadi Button cari. e) Bentuk huruf. f) Penambahan button print pada data buku dan data anggota.

Sedangkan untuk button halaman depan yang terdapat pada form peminjaman buku terdapat juga perubahan berdasarkan hasil wawancara dengan ahli media, yaitu antara lain: a) Nama button data buku dan data anggota. b) Penambahan button preview (tombol tinjau) data peminjam yaitu untuk melakukan preview pada data peminjam sebelum data di- print. c) Penambahan button print (tombol cetak) data peminjam yaitu untuk mencetak data peminjam.

3) Desain Query

Pada desain query dilakukan penambahan kolom judul buku dan jumlah buku, perubahan dilakukan berdasarkan hasil wawancara dengan ahli materi dan ahli media

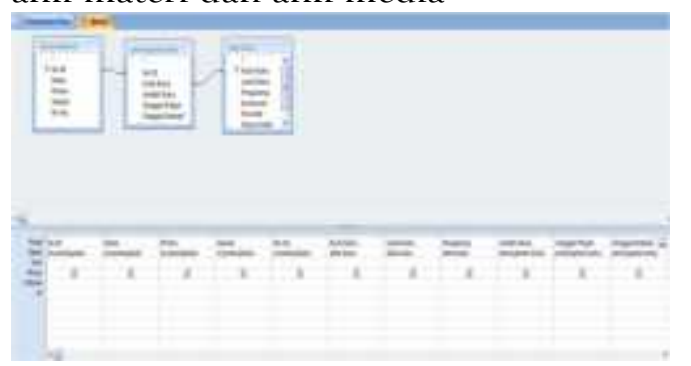

Gambar 6 Desain Query Data

4) Desain Report Peminjaman Buku

Pada desain report sama halnya dengan query yaitu penambahan judul buku dan jumlah buku.

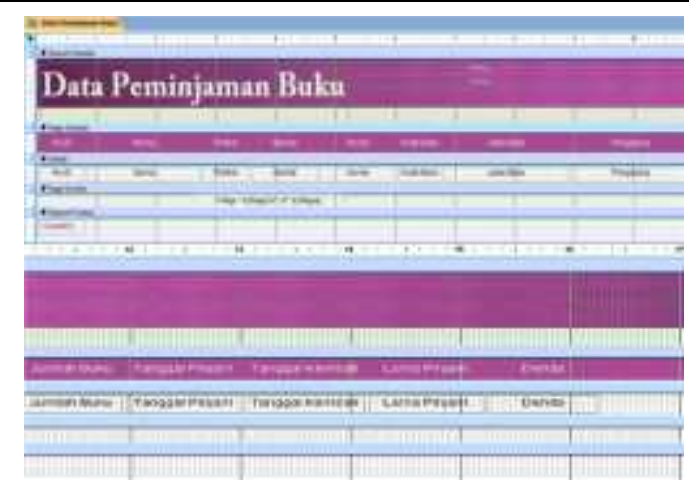

Gambar 7 Desain Report Data Peminjaman Buku

3. Percobaan (testing)

Setelah melakukan desain akhir dari sistem yang telah dibuat, kemudian melakukan percobaan terhadap sistem tersebut antara lain:

a. Membuka aplikasi apakah bisa dibuka setelah di-compile.

b. Mencoba input data pada form peminjaman buku, data anggota, dan data buku.

c. Mengklik semua button tambahkan, simpan, hapus, keluar dan cari pada masing-masing form. Tujuannya untuk dapat mengetahui apakah button dapat berfungsi untuk menambahkan, menyimpan, menghapus, dan keluar dari form.

d. Mengklik button data buku dan data anggota. Tujuannya untuk mengetahui apakah setelah mengklik button tersebut langsung masuk ke form yang dituju atau tidak.

e. Mengklik button peminjam. Tujuannya untuk mengetahui apakah memang dapat memanggil report data peminjam buku atau tidak.

f. Mengklik button preview data peminjaman. Tujuannya untuk mengetahui apakah preview data peminjam bisa dilakukan atau tidak.

g. Melakukan print data peminjam dan setup data.

Jika sudah selesai melakukan uji coba dan sistem yang telah dicoba sudah sesuai serta tidak ada yang harus diperbaiki, maka sistem tersebut sudah bisa diimplementasikan. 


\section{KESIMPULAN}

Dari perancangan sistem peminjaman buku di perpustakaan SMAN 2 Woha berbasis Microsoft Access 2007 ini, maka dapat ditarik beberapa kesimpulan antara lain:

1. Semoga hasil dari tahapan persiapan dan uji coba perancangan sistem peminjaman dan pengembalian buku menggunakan aplikasi Microsoft Access 2007 ini dapat diterima dengan baik oleh pihak sekolah dan dapat dimanfaatkan dengan baik.

2. Dengan adanya aplikasi sistem peminjaman buku ini semoga dapat meningkatkan kinerja dalam rangka melakukan pelayanan kepada peminjam.

3. Sistem peminjaman buku ini mudah digunakan oleh petugas perpustakaan (user friendly).

4. Dapat menghemat waktu untuk pencarian, pencatatan, dan pemasukan data dengan mudah.

5. Dengan tahapan cara merancang komponenkomponen utama yang terdapat pada Microsoft Access 2007 ini semoga nantinya tidak menimbulkan masalah pada saat sistem sedang dijalankan.

\section{DAFTAR PUSTAKA}

Anonim. 2015."Pengertian dan Fungsi Microsoft Access". Tersedia pada http://www.siswamaster.com/2015/10/pen gertian-dan-fungsi-microsoft access.html\#ixzz4bs1J6pzv, diakses Sabtu, 4 Februari 2017, pukul 15.40 WITA.

Mulyana, Aina. 2016. "Pengertian dan Manfaat Perpustakaan Sekolah”. Tersedia pada http://ainamulyana.blogspot.com/2016/01 /perpustakaan-sekolah- pengertianmanfaat.html, diakses Sabtu, 4 Februari 2017, pukul 15.49 WITA.

Jannah, Nur. 2015. "Pengertian dan Fungsi Pada Microsoft Access". Tersedia pada https://norjannahteknologi.wordpress.com /2015/10/04/pengertian- dan-fungsi-padamicrosoft-access/, diakses Sabtu, 4 Februari 2017, pukul 16.19 WITA.

Setiya, Andi. 2013. "Pengembangan Sistem Informasi Dengan Metode Wterfall”.
Tersedia pada http://Andisetiya.Blog.Widyatama.Ac.Id/2 013/10/02/PengembanganSistemInformasi-Dengan-Metode-Waterfall/, diakses Sabtu, 4 Februari 2017, pukul 17.27 WITA.

Wahyuni, Putri \& Ardoni. 2014. "Perancangan Database Peminjaman dan Pengembalian Buku di Perpustakaan SMKN Padang Panjang Berbasis Microsoft Access”. Disertasi tidak diterbitkan. Padang: Program Studi Ilmu Informasi Perpustakaan dan Kearsipan Universitas Negeri padang.

Chandra, Andhika \& Prayudha, Lukman Hindra. 2012. "Sistem Informasi Perpustakaan Berbasis Microsoft Access Pada Sekolah Tinggi Kejuruan ALAMNANIYAH di Ngawi”. Disertasi tidak diterbitkan. Madiun: Program Studi Teknik Informatika Sekolah Tinggi Teknologi Dharma Iswara Madiun.

Fauzan, Reza Milady. 2008. "Perancangan Sistem Pemesanan Produk Berbasis WEB Pada CV. Hanif Niaga Group”. Disertasi tidak diterbitkan. Jakarta: Fakultas Sains Dan Teknologi Universitas Islam Negeri Syarif Hidayatullah Jakarta.

Multazam, Ahmad. 2013. "Pemanfaatan Perpustakaan Sebagai Sumber Belajar”.Tersedia pada http://multazam einstein.blogspot.co.id/2013/06/pemanfaat an-perpustakaan-sebagai- sumber.html, diakses Senin, 7 April 2017, pukul 18.11 WITA.

Anonim. 2015. "Metode Pengembangan Sistem". Tersedia pada http://metodepengembangansistem.blogspo t.co.id/2015/02/model- waterfall.html, diakses Senin, 7 April 2017, pukul 18.20 WITA.

Anonim. 2014. "Microsoft Office Access". Tersedia pada http://alviescoot.blogspot.co.id/2014/09/ microsoft-office-access-2007.html, diakses Senin, 7 April 2017, pukul 19.12 WITA.

Anonim. 2012. "Makalah Microsoft Access". Tersedia pada http://makalahlaporanterbaru1.blogspot.co. 
id/2012/03/makalah-microsoftaccess.html, diakses Sabtu, 4 Februari 2017, pukul 16.05 WITA.

Wulanen, Nur. "Landasan Teori Perancangan Sistem Informasi Akuntansi”. http://elib.unikom.ac.id/download.php?id= 15694. Diakses Senin, 7 April

2017, pukul 20.22 WITA.

Inolungan, Joulis. 2014. "Pengembangan Sistem Teknologi Informasi Metode Sdlc”. Tersedia pada

https://joulisinolungan.wordpress.com/201 4/12/10/pengembangan-sistem- teknologiinformasi-metode-sdlc-system-developmentlife-cycle/, diakses Sabtu, 4 Februari 2017, pukul 17.44 WITA.

Rosa. 2015. "Metode Pengembangan Sistem". Tersedia pada http://metodepengembangansistem.blogspo t.co.id/2015/02/sdlc-air-terjun- waterfallmenurut-rosa.html, diakses Sabtu, 4 Februari 2017, pukul 17.50

WITA.

Sasrawan, Herdi. 2014. "Pengertian Sistem Menurut Para Ahli”. Tersedia pada http://hedisasrawan.blogspot.co.id/2014/0 1/25-pengertian-sistem-menurut-paraahli.html, diakses Minggu, 30 April 2017, pukul 15.01 WITA. 